\title{
KARAKTERISTIK MUTU KIMIA DAN BIOLOGI COCOGURT DENGAN PERBEDAAN KONSENTRASI PEKTIN DAN PISANG SEBAGAI PREBIOTIK ALAMI
}

\section{Chemical and Biological Characteristics of Cocogurt with Different Concentrations of Pectin and Banana as Natural Prebiotics}

\author{
Irna Dwi Destiana*, Devi Aprilia, Sri Hermalia \\ Jurusan Agroindustri, Politeknik Negeri Subang \\ *irnadwidestiana@polsub.ac.id
}

\begin{abstract}
ABSTRAK
Cocogurt atau coconut yoghurt merupakan minuman probiotik berbahan dasar susu atau santan kelapa yang difermentasi dengan bantuan bakteri asam laktat (BAL). Penambahan pisang berperan sebagai prebiotik fasilitator bakteri asam laktat, sedangkan pektin untuk memperbaiki tekstur. Penelitian ini bertujuan untuk mengetahui pengaruh perbedaan penambahan konsentrasi pisang dan pektin terhadap karakteristik mutu kimia dan biologi cocogurt. Sampel yang diamati adalah 3 formulasi terbaik yang diperoleh dari 16 formulasi hasil penelitian sebelumnya. Hasil pengukuran dan analisis sidik ragam dengan alfa $5 \%$ dilanjutkan dengan Uji Duncan Multiple (DMRT) dengan selang kepercayaan 5\%. Penambahan perbedaan konsentrasi prebiotik memberikan pengaruh nyata terhadap kadar lemak dan total bakteri asam laktat, namun penambahan perbedaan konsentrasi pisang dan pektin tidak berpengaruh nyata terhadap kadar abu dan kadar protein. Penambahan pisang berbanding terbalik dengan kadar protein, namun berbanding lurus dengan total bakteri asam laktat.
\end{abstract}

Kata kunci: cocogurt, pektin, pisang, susu kelapa

\begin{abstract}
Cocogurt or coconut yogurt is a probiotic drink made from coconut milk which is fermented bylactic acid bacteria. The addition of bananas acts as a prebiotic facilitator for lactic acid bacteria while pectin can improve texture. The research aims to determine the effect of different concentrations of banana and pectin addition to the chemical and biological quality characteristics of cocogurt. Observed samples for this research was 3 best formulations which obtained by 16 formulations of previous research results. Measurement results and analysis of variance with $5 \%$ alpha followed by Duncan Multiple Test with a confidence interval of $5 \%$. The different concentration of prebiotic had a significant effect on fat content and total lactic acid bacteria, but not significant on ash content and protein content. The addition of bananas is inversely propotional to protein content while directly proportional to the total lactic acid bacteria.
\end{abstract}

Keywords: banana, cocogurt, coconut milk, pectin

\section{PENDAHULUAN}

Kelapa menjadi salah satu komoditi terbesar di Indonesia yang banyak dimanfaatkan dalam olahan pangan. Susu kelapa atau yang biasa dikenal masyarakat santan kelapa merupakan salah satu produk hasil olahan kelapa yang diperoleh dari proses pemerasan parutan daging kelapa dengan atau tanpa penambahan air (Panca, 2016). Proses pengolahannya dapat dilakukan dalam skala industri rumah tangga dengan cara sederhana, sedangkan dalam skala industri makro santan atau susu kelapa dapat dikemas dalam bentuk cair maupun bubuk. Susu atau santan kelapa tanpa bahan tambahan pengawet memiliki daya simpan yang cenderung mudah rusak dan mudah tengik, sehingga perlunya upaya untuk meningkatkan citarasa dan waktu simpan terhadap susu atau santan kelapa (Yanuar, 1992). Salah satu alternatif lain untuk meningkatkan umur simpan susu atau santan kelapa adalah mengolahnya menjadi minuman probiotik seperti yoghurt. 
Cocogurt atau coconut yoghurt merupakan minuman probiotik berbahan dasar susu kelapa yang difermentasi dengan bantuan bakteri asam laktat (BAL). Pada umumnya, yoghurt terbuat dari susu sapi atau susu kedelai. Dilihat dari segi ekonomi, susu sapi memiliki harga relatif lebih mahal dibandingkan susu nabati, sedangkan susu kedelai di Indonesia sendiri produksi bahan bakunya masih terbilang kurang untuk memperolehnya harus menyuplai dari luar. Menurut FOA/WHO (2002), probiotik merupakam mikroba hidup yang jika dikonsumsi dalam jumlah yang memadai akan bermanfaat terhadap kesehatan pejamunya.

Proses fermentasi cocogurt seperti pembuatan yoghurt pada umumnya yang memerlukan sumber prebiotik sebagai fasilitator selektif untuk aktivitas ataupun pertumbuhan bakteri asam laktat. Adapun yang menjadi sumber prebiotik pada penelitian cocogurt kali ini adalah pisang. Pisang (Musa paradisiaca) merupakan salah satu sumber prebiotik alami dengan kandungan gula yang cukup tinggi, yaitu senyawa Inulin dan Fruktooligosakarida (FOS), senyawa yang tidak dapat tercerna di dalam saluran pencernaan (Hardisari \& Amaliawati, 2016). Dalam perannya, senyawa Inulin dan Fruktooligosakarida (FOS) pada pisang akan memfasilitasi bakteri pengubah laktosa (gula susu) menjadi asam laktat (Purwiyanto \& Hariyadi, 2005). Selain penambahan pisang sebagai prebiotik alami, pektin juga ditambahkan untuk meningkatkan kekentalan dan perbaikan tekstur pada suatu poduk atau bahan (Winarno, 1984). Arioui, et al. (2016) melakukan penelitian pektin hasil ekstraksi jeruk manis yang ditambahkan pada yoghurt, hasil menunjukan semakin tinggi konsentrasi pektin yang ditambahkan, maka akan berbanding lurus dengan viskositas yoghurt.

Penelitian ini dilakukan untuk mengetahui pengaruh penambahan perbedaan konsentrasi pektin dan pisang sebagai prebiotik alami terhadap karakteristik kimia dan biologi pada tiga formulasi terbaik cocogurt, hasil dari penelitian yang telah dilakukan sebelumnya.

\section{METODE}

\section{Bahan dan Alat Penelitian}

Bahan yang digunakan: kelapa, air kelapa, pisang, pektin, starter, gula pasir, MRS Broth, heksana, spirtus, kertas saring, $\mathrm{H} 2 \mathrm{SO} 4, \mathrm{H} 3 \mathrm{BO} 3$ aquades, spirtus, BCG MR.

Alat yang digunakan: baskom, kompor, sendok, wadah kemasan, sendok kecil, tissue, cling wrap, blender, gelas ukur, gelas piala, hot plate, spindel, sudip, tanur, inkubator, labu lemak, erlenmayer, neraca analitik, tabung ulir, termometer, 1 set alat soxhlet, desikator, krustang, cawan porslen, cawan petri, loyang, mikro pipet, autoclav, rotary evaporator.

Formulasi cocogurt yang diujikan merupakan formulasi terbaik yang diperoleh dari 16 sampel penelitian yang telah dilakukan sebelumnya, kemudian dilakukan pengujian kadar abu, kadar lemak, kadar protein kasar dan TPC. Masing-masing 3 formulasi tersebut teridiri dari sampel : $\alpha 2 \beta 2$ (7.5\% prebiotik pisang, $1 \%$ pektin); $\alpha 2 \beta 3$ (7.5\% prebiotik pisang, 1.5\% pektin); dan $\alpha 4 \beta 3$ (12.5\% prebiotik pisang, $1.5 \%$ pektin).

\section{HASIL DAN PEMBAHASAN}

Kenampakan 3 formulasi cocogurt secara umum memiliki tekstur yang kental karena adanya penambahan pektin, berwarna putih keruh hasil dari homogenisasi seluruh bahan, rasa khas campuran pisang dengan susu atau santan kelapa yang asam seperti yoghurt pada umumnya, dan aroma khas campuran pisang dan susu atau santan kelapa. Ke 3 formulasi tersebut diujikan secara kimia meliputi kadar abu, kadar lemak dan kadar protein, serta diujikan biologi yaitu total bakteri asam laktat. Adapun hasil pembahasan dari masing-masing parameter sebagai berikut:

\section{Kadar Abu}

Tabel 1. Hasil Analisis Kadar Abu (\%)

\begin{tabular}{lll}
\hline Formulasi & $\%$ Abu & SNI 01.2981-2009 (\%) \\
\hline$\alpha_{4} \beta_{3}$ & $0.63^{\mathrm{a}}$ & Maks. 1.0 \\
$\alpha_{2} \beta_{2}$ & $0.64^{\mathrm{a}}$ & \\
$\alpha_{2} \beta_{3}$ & $0.78^{\mathrm{a}}$ & \\
\hline
\end{tabular}


Berdasarkan Tabel 1. Hasil Analisis Kadar Abu, perbedaan penambahan konsentrasi pisang dan pektin dari ke 3 formulasi cocogurt tidak menunjukkan pengaruh nyata. Kadar abu pada cocogurt diketahui mengandung komponen mineral mikro dan makro yang relatif stabil dibandingkan kandungan atau komponen lainnya (Buckle, et al., 1987). Di samping itu, kadar abu dapat dipengaruhi oleh bahan baku dan bahan tambahan lain yang digunakan dalam pengolahan (Syaputra, et al., 2015). Diduga kadar abu yang terkandung pada masing-masing formulasi cocogurt relatif rendah.

Ke 3 formulasi cocogurt yang diujikan memiliki kadar abu berkisar di bawah 1.0\%. Dengan demikian, ke 3 formulasi cocogurt tersebut masih memenuhi kriteria batasan yang ditetapkan oleh SNI 01.2981-2009 minuman yoghurt, yaitu kadar abu maksimal 1.0\%.

\section{Kadar Lemak}

Tabel 2. Hasil Analisis Kadar Lemak (\%)

\begin{tabular}{lll}
\hline Formulasi & \% Lemak & SNI 01.2981-2009 (\%) \\
\hline$\alpha_{4} \beta_{3}$ & $2.04^{\mathrm{a}}$ & Maks. 3.0 \\
$\alpha_{2} \beta_{2}$ & $3.49^{\mathrm{a}}$ & \\
$\alpha_{2} \beta_{3}$ & $6.06^{\mathrm{b}}$ & \\
\hline
\end{tabular}

Berdasarkan Tabel 2. Hasil Kadar Lemak, menunjukan adanya pengaruh nyata. Kadar lemak terendah terdapat pada formulasi cocogurt $\alpha_{4} \beta_{3}$ (12.5\% prebiotik pisang, $1.5 \%$ pektin). Rendahnya kandungan lemak pada formulasi tersebut dapat dipengaruhi oleh adanya proses hidorolisis lemak, dimana lemak akan terurai dengan bantuan bakteri asam laktat yang sengaja ditumbuhkan. Jumlah bakteri tersebut menjadi salah satu penentu kadar lemak yang terkandung pada suatu produk atau bahan. Hal ini terlihat dari Tabel 4. Hasil Total Bakteri Asam Laktat menunjukkan korelasi antara jumlah bakteri asam laktat yang tumbuh dengan kadar lemak pada cocogurt. Semakin banyak jumlah bakteri asam laktat, maka akan semakin banyak pula lemak yang terurai, sehingga kadar lemak yang terkandung pada cocogurt akan semakin sedikit. Pertumbuhan bakteri ini tidak lepas dari dukungan penambahan pisang sebagai mediatornya. Pisang (Musa paradisiaca) merupakan mediator tumbuh bakteri karena mengandung sumber prebiotik alami, yaitu kandungan gula yang cukup tinggi seperti senyawa Inulin dan Fruktooligosakarida (FOS), senyawa tersebut tidak dapat tercerna di dalam saluran pencernaan (Hardisari \& Amaliawati, 2016). Jumlah bakteri asam laktat yang meningkat dalam mediator fermentasi akan menghidrolisis atau mengurai lemak sehingga menjadi senyawa-senyawa yang lebih sederhana, hal ini mengakibatkan kandungan lemak pada suatu bahan atau produk menurun (Syaputra, et al., 2015).

Berdasarkan SNI 01.2981-2009 mengenai ketentuan kadar lemak syarat batasan maksimal minuman yogurt yang ditetapkan yaitu 3.0\%. Dengan demikian, hanya formulasi $\alpha_{4} \beta_{3}(12.5 \%$ prebiotik pisang, $1.5 \%$ pektin) yang memiliki kadar lemak yang memenuhi standar tersebut.

\section{Kadar Protein}

Tabel 3. Hasil Analis Kadar Protein Kasar (\%)

\begin{tabular}{lll}
\hline Formulasi & $\%$ Protein & SNI 01.2981-2009 (\%) \\
\hline$\alpha_{4} \beta_{3}$ & $0.66^{\mathrm{a}}$ & Min. 2.7 \\
$\alpha_{2} \beta_{2}$ & $0.61^{\mathrm{a}}$ & \\
$\alpha_{2} \beta_{3}$ & $0.79^{\mathrm{a}}$ & \\
\hline
\end{tabular}

Berdasarkan Tabel 3. Hasil Analisis Kadar Protein Kasar dengan metode Kjeldhal didapatkan data yang memperlihatkan bahwa penambahan perbedaan konsentrasi pisang dan pektin tidak berpengaruh nyata terhadap 3 formulasi yang diujikan.

Susu atau santan kelapa sebagai bahan baku utama memiliki kadar protein yang tidak terlalu tinggi. Kadar protein susu atau santan kelapa memiliki kandungan protein sebesar $2.3 \mathrm{~g} / 100 \mathrm{~g}$ sedangkan buah kelapa kandungan proteinnya sebesar 3.4 - $4.0 \mathrm{~g}$ (Sinaga, 2017). Menurut Sukaesih, et al. (2009) susu atau santan kelapa yang tidak melalui proses pemanasan sebesar $2.76 \%$, sedangkan jika melalui pemanasan kadar protein menurun berada pada rentang 1.17-2.76\%. Pada proses pengolahan cocogurt sendiri melalui beberapa tahap proses pemanasan, sehingga kemungkinan kandungan protein pada masing-masing formulasi cocogurt mengalami penurunan seiring dengan 
kenaikan suhu pemanasan. Hal ini karena kadar protein pada suatu bahan tersebut yang mengalami denaturasi protein, sehingga rantai ikatan antar asam amino menjadi terputus (Sukaesih, et al., 2009).

Jika mengikuti aturan kriteria minuman yoghurt menurut SNI 2981:2009 yang mensyaratkan kadar protein minimal $2.7 \%$, maka ke 3 formulasi cocogurt ini belum memenuhi standar mutu yang sudah ditetapkan.

\section{Bakteri Asam Laktat}

Tabel 4. Hasil Total Bakteri Asam Laktat

\begin{tabular}{lll}
\hline Formulasi & Log Jumlah BAL $(\mathrm{CFU} / \mathrm{ml})$ & SNI 01.2981-2009 $(\mathrm{CFU} / \mathrm{ml})$ \\
\hline$\alpha_{4} \beta_{3}$ & TBUD & Min. 107 \\
$\alpha_{2} \beta_{2}$ & $1.7 \times 10^{6}$ & \\
$\alpha_{2} \beta_{3}$ & $2.3 \times 10^{5}$ & \\
\hline
\end{tabular}

Berdasarkan Tabel 4. Hasil Total Bakteri Asam Laktat, menunjukan adanya perbedaan nyata.

Pertumbuhan bakteri asam laktat dapat dipengaruhi oleh fasilitator penunjangnya. Pada formulasi $\alpha_{4} \beta_{3}$ (12.5\% prebiotik pisang, $1.5 \%$ pektin) memiliki kandungan bakteri asam laktat tertinggi. Hal ini disebabkan karena pada formulasi tersebut konsentrasi pisang sebagai mediator alami yang lebih tinggi dibandingkan ke 2 formulasi lain. Pernyataan tersebut sejalan dengan penelitian yang dilakukan oleh Hardisari dan Amaliawati (2016) hasil penelitiannya menunjukkan penambahan konsentrasi tepung pisang kepok berbanding lurus dengan pertumbuhan bakteri probiotik Lactobacillus casei. Faktor yang memengaruhi viabilitas bakteri asam laktat dan kecepatan pertumbuhannya selama proses fermentasi ditentukan oleh kandungan serta kesesuain nutrisi yang ada pada media fermentasi tersebut (Nisa, et al., 2008). Pisang memiliki kandungan senyawa Inulin dan Fruktooligosakarida (FOS) yang mampu memfasilitasi tumbuhnya bakteri pengubah laktosa (gula susu) menjadi asam laktat (Purwiyanto \& Hariyadi, 2005).

Di samping itu, pisang merupakan media selektor yang hanya dapat memfasilitasi pertumbuhan bakteri baik saja. Kandungan prebiotiknya memiliki karakterisitik yang tahan terhadap enzim saluran pencernaan pada usus manusia, namun dapat difermentasi oleh koloni mikroflora dan bifofogenik, serta karakter lainnya yaitu efek $\mathrm{pH}$ rendah. Efek tersebut menjadi penghalang bakteri yang berpotensi patogen (Atarini, 2011). Dapat diketahui dari hasil pengujian total bakteri asam laktat pada ke 3 formulasi cocogurt, penambahan bakteri asam laktat mampu memanfaatkan pisang sebagai fasilitator alami sebagai tempat berkembang biaknya dengan baik.

Berdasarkan aturan Standar Nasional Indonesia (SNI) 2981:2009 yang menyatakan bahwa jumlah minimal total BAL dalam yoghurt sebanyak $10^{7} \mathrm{CFU} / \mathrm{ml}$. Dengan demikian, hanya formulasi $\alpha_{4}$ $\beta_{3}(12.5 \%$ prebiotik pisang, $1.5 \%$ pektin) yang memenuhi syarat ketentuan tersebut.

\section{KESIMPULAN}

Hasil analisis masing-masing parameter ke 3 formulasi cocogurt yang diujikan, kemudian dianalisis sidik ragam dengan alfa 5\% dilanjutkan dengan Uji Duncan Multiple (DMRT) dengan selang kepercayaan $5 \%$, diperoleh bahwa penambahan perbedaan konsentrasi prebiotik memberikan pengaruh nyata terhadap kadar lemak dan total bakteri asam laktat, namun penambahan perbedaan konsentrasi pisang dan pektin tidak berpengaruh nyata terhadap kadar abu dan kadar protein. Penambahan pisang berbanding terbalik dengan kadar protein, namun berbanding lurus dengan total bakteri asam laktat.

\section{UCAPAN TERIMAKASIH}

Penulis mengucapkan terima kasih yang sebesar-besarnya kepada DITJEN BELMAWA Kementerian Pendidikan dan Kebudayaan atas kesempatan dan dana yang telah diberikan untuk kegiatan penelitian ini. 


\section{DAFTAR PUSTAKA}

AOAC. (1995). Official Methods of Analisys Chemist. Volume 1 A.

Arioui, F., Saada, D. A. \& and Cheriguene. A. (2016). Physicochemical and Sensory Quality of Yogurt Incorporated with Pectin from Peel of Citrus sinensis.

Atarini, A. A. N. (2011). Sinbiotik antara Prebiotik dan Probiotik. Jurnal IImu Gizi, Volume 2(2), pp. 148155.

Badan Standarisasi Nasional. (2009). SNI Yoghurt (SNI 2981:2009). Jakarta: Dewan Standardisasi Nasional.

Buckle, K. A. R. A., Edward, G., Fleet, H. \& Wootton, M. (1987). Ilmu Pangan. Jakarta: Universitas Jakarta.

Food Agricultural Organization/ World Health Organization. (2002). Guidelines for The Evaluation of Probiotics in Food. Report of a Joint FAO/WHO Working Group on Drafting Guidelines for The Evaluation of Probiotic in Food Ontario. Canada.

Fardiaz. (1993). Analisis Mikrobiologi Pangan. Jakarta: PT. Raja Grafindo Persada.

Hardisari, Amaliawati. (2016). Manfaat Prebiotik Tepung Pisang Kepok (Musa paradisiaca formatypica) terhadap Pertumbuhan Probiotik Lactobacillus casei secara In Vitro. J. Teknologi Laboraturium, Volume 5(2), pp. 64-67.

Nisa, F. C., J, K., Crisnasar. (2008). Viabilitas dan Deteksi Subletal Bakteri Probiotik pada Susu Kedelai Fermentasi Instan Metode Pengeringan Beku (Kajian Jenis Isolat dan Konsentrasi Sukrosa sebagai Krioprotektan). Jurnal Teknologi Pertanian, Volume 9(10), pp. 40-51.=]

Panca, V. (2016). Penyusunan Instruksi Kerja Pembuatan Santan Awet dalam Kemasan Standing Pouch. Skripsi. Institut Pertanian Bogor.

Purwiyanto, Hariyadi. (2005). Southest Asian Food and Agricultural Science and Technology (SEAFAST).

Sinaga. E. H., A. F. S. B. S. (2017). Pembuatan Virgin Coconut Oil (VCO) dari Kelapa Hibrida dengan Metode Enzimatis dan Aplikasinya Sabun Padat Transparan. Jurnal Chemurgy, pp. 16-21.

Sukaesih, E., Prabawati, S., Hidayat, T. (2009). Optimasi Kecukupan Panas pada Pasteurisasi Santan dan Pengaruhya terhadap Mutu Santan yang Dihasilkan. J. Pascapanen, Volume 6(1), pp. 3442.

Syaputra, A., Pato, U., Rossi, E. (2015). Variasi Penambahan Sukrosa terhadap Mutu Cocoghurt Menggunakan Enterococcus faecalis Up-11 yang Diisolasi dari Tempoyak. Jom Faperta, Volume 2(1).

Winarno. (1984). Kimia Pangan dan Gizi. Jakarta: PT. Gramedia Pustaka.

Yanuar, T. (1992). Studi Mutu Yoghurt Santan Kelapa Selama Peyimpanan.

Yitnosumarto. (1993). Percobaan Perancangan Analisis, dan Interpretasinya. Jakarta: PT Gramedia Pustaka Utama. 